\title{
Article \\ Toxic Metal Concentrations in Drinking Water and Possible Effect on Sex Hormones among Men in Sabongida-Ora, Edo State, Nigeria
}

\author{
Osaro Ogie Enehizena and Mathias A. Emokpae *D
}

Citation: Enehizena, O.O.; Emokpae, M.A. Toxic Metal Concentrations in Drinking Water and Possible Effect on Sex Hormones among Men in Sabongida-Ora, Edo State, Nigeria. Medicines 2022, 9, 4. https:// doi.org/10.3390/medicines 9010004 Academic Editor: Hiroshi Sakagami and George J. Kontoghiorghes

Received: 12 November 2021

Accepted: 3 January 2022

Published: 7 January 2022

Publisher's Note: MDPI stays neutral with regard to jurisdictional claims in published maps and institutional affiliations.

Copyright: (C) 2022 by the authors. Licensee MDPI, Basel, Switzerland. This article is an open access article distributed under the terms and conditions of the Creative Commons Attribution (CC BY) license (https:// creativecommons.org/licenses/by/ $4.0 /)$.
Department of Medical Laboratory Science, School of Basic Medical Sciences, University of Benin, Benin 300283, Nigeria; enehizenaosaro@gmail.com

* Correspondence: mathias.emokpae@uniben.edu; Tel.: +234-803-451-1182

\begin{abstract}
Drinking water can be a potential source of toxic metals, which are a known leading cause of infertility in men. This study determines the concentrations of lead $(\mathrm{Pb})$, cadmium $(\mathrm{Cd})$, zinc $(\mathrm{Zn})$, copper $(\mathrm{Cu})$ in drinking water (borehole, hand-dug well and treated water) and sex hormone levels (serum follicle stimulating hormone (FSH), luteinizing hormone (LH), prolactin (PROL), estradiol (E2), progesterone (PROG), and testosterone $(\mathrm{T})$ in males who drink water mainly from these sources. The concentrations of $\mathrm{Cd}$, and $\mathrm{Pb}$ in hand-dug wells were higher than the permissible limit recommended by the World Health Organization (WHO) while $\mathrm{Zn}$ and $\mathrm{Cu}$ were within the permissible levels in drinking water. Blood $\mathrm{Cd}$ and $\mathrm{Pb}$ levels were significantly higher $(p<0.001)$ among subjects who consumed hand-dug and borehole water than treated water, while serum $\mathrm{Zn}$ was significantly lower $(p<0.001)$ in hand-dug well and borehole water consumers than in control subjects. Also, serum FSH $(p<0.001)$, LH $(p<0.001)$, E2 $(p<0.002)$, PROG $(p<0.04)$ and T $(p<0.001)$ were significantly lower among hand-dug well and borehole water consumers than controls, while PROL $(p<0.001)$ was significantly higher in hand-dug well and borehole water consumers than controls. Blood Cd and $\mathrm{Pb}$ levels were significantly higher $(p<0.001)$ in hand-dug well water consumers than borehole water consumers. The consumption of water from hand-dug wells may have adverse reproductive sequelae among consumers.
\end{abstract}

Keywords: male; drinking water; gonadal steroid hormones; Nigeria

\section{Introduction}

Water safety and quality are very important for human development and well-being. Besides the pathogenic risk of harmful microorganisms, several chemical contaminants are present in water as a result of human activities (anthropogenic) which could be risk factors to human and animal health $[1,2]$. Some authors have indicated that the contaminants in water could impair development, fertility and reproductive function in non-human mammals, humans, and aquatic wild life. Others have observed that exposure to water disinfection byproducts in drinking water can lead to cardiac disorders in animal models [3,4]. Furthermore, exposure to bisphenol A (BPA) and phthalates are reported to cause decline in fecundity by premature activation of primordial follicles in mammals as well as changes in sex-steroid hormone levels [5-9]. Some have suggested that pesticides contaminants in drinking water might impact reproductive health. Studies have suggested that exposure to some pesticides was associated with low sperm quality and quantity as well as adverse pregnancy outcomes in both animals and humans $[10,11]$.

The toxic metals found in drinking-water come from contamination of surface and ground waters by industrial sewage and agricultural runoff. In some communities where treated water distribution network is a challenge, those who cannot afford bottled or mineral water with controlled toxic metal concentrations have no alternative than to consume hand-dug well, borehole or tap water. Therefore, the possible contamination of 
drinking water with toxic metals and subsequent accumulation are greatly increased [12]. The quality control of drinking-water and detection of its toxic metals is an extremely critical issue in order to maintain sound human health [13]. Toxic metals can bioaccumulate in organisms because of their long half-life [14]. Toxic metals often bind to vital cellular components, such as structural proteins, enzymes, and nucleic acids, and interfere with their functions [15]. Symptoms and effects can vary according to the metal or metal compound and the dose involved. Generally, long-term exposure to toxic metals can have carcinogenic, central and peripheral nervous system and circulatory effects.

Circulating levels of the follicle stimulating hormone (FSH), the luteinizing hormone $(\mathrm{LH})$, prolactin and testosterone are vital for spermatogenesis and sexual function. The accumulation of toxic metals in the body is harmful to sexual function and reproduction. Therefore, the evaluation of toxic levels in drinking water and the possible effect on reproductive hormones is important for public health information.

In developing countries like Nigeria, the quality of drinking water is increasingly contaminated and hazardous to human health because of high population growth, expansion in industries, indiscriminate dumping of waste and chemical effluents in to canals and other water sources [16]. Some authors have suggested that frequent studies of the quality of drinking water should be undertaken. Since groundwater is directly in contact with soil, rocks, and plants, the constituents of these sources might contaminate the groundwater [17-19]. The quality control of drinking-water and the assessment of its toxic metals contents is extremely critical and is of public health importance. Studies have indicated that male infertility due to endocrine abnormalities is common in Nigeria [20-22] and the exact causes are not known. This study seeks to determine the concentrations of $\mathrm{Pd}, \mathrm{Cd}$, $\mathrm{Zn}$ and $\mathrm{Cu}$ in hand-dug well, borehole and treated water, the blood levels of these metals as well as sex hormones in subjects who drink water solely from these sources. This will provide evidence to indicate if the levels of these metals in the drinking water are higher or within the WHO permissible levels and their possible association with sex hormones among the subjects who drink water solely from these sources.

\section{Materials and Methods}

\subsection{Study Area and Water Sample Collection}

The study was conducted at Sabongida Ora, Owan West Local Government Area of Edo State among men who drink water solely from hand-dug well, borehole and treated sources.

Water samples were randomly selected across ten (10) locations in Sabongida-Ora, $15 \%$ were from Ohia, 10\% from Borehole road, 5\% were from Holy Trinity Grammar School Road, 20\% from Uhonmora, 20\% from Evbiobe,10\% Living Faith Church, Sabongida-Ora Road, 5\% were from Oke, 5\% were from Ovbiokhuarin and 5\% were from Eme and 5\% from Owan West Local Government Secretarial. Water samples were collected in clean-glass containers washed by soaking in $20 \%(v / v)$ Nitric acid for $24 \mathrm{~h}$ and rinsed with several changes of tripled distilled water and dried in a polypropylene container. Sampling was conducted early in the morning before water abstraction commenced by residents. Two separate samples per water source were collected for analysis.

\subsection{Sample Size Determination}

The sample size for hormonal evaluation was determined using the sample size determination formula for Health studies $N=Z^{2} P(1-P) / d^{2}$ [23] where $n=$ minimum sample size, $\mathrm{P}=$ estimated prevalence, $\mathrm{Z}=$ standard normal deviate that corresponds to $95 \%$ confidence limit (1.96), $\mathrm{d}^{2}$ is the alpha level of significance $(5 \%)$ and the prevalence of hormonal abnormalities in occupationally exposure subjects to toxic metal contamination (96.7\%) [24]. As a result, a minimum of 60 participants and 30 non-occupationally exposure healthy subjects were enrolled in the study. Figure 1 shows the location in Nigeria where the study was conducted. 

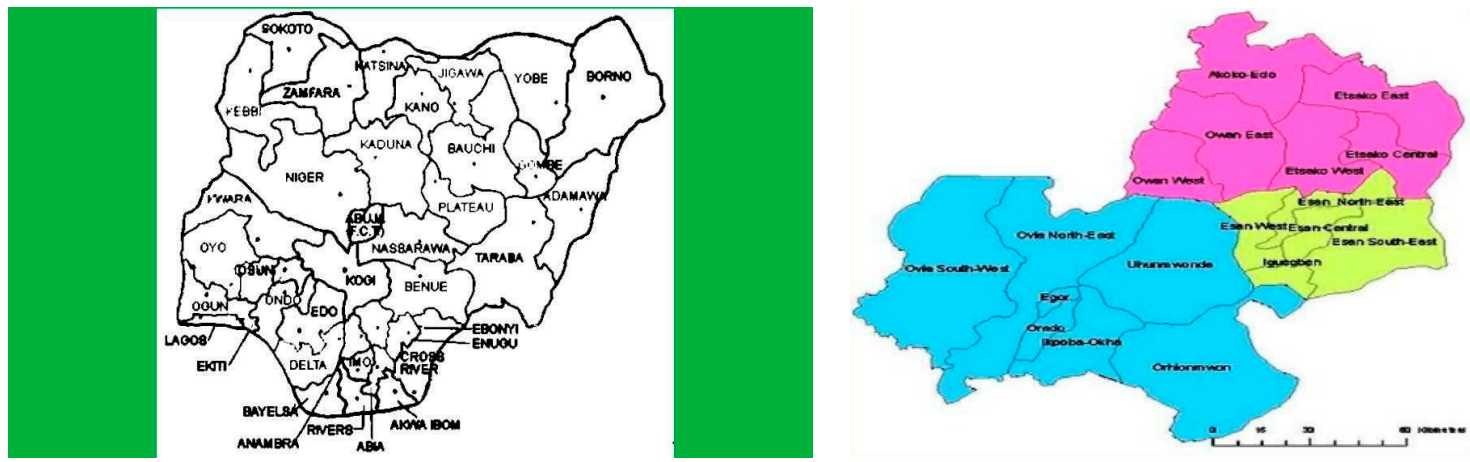

Figure 1. Map of Nigeria and Edo State in Nigeria.

Ten boreholes and ten hand dug well water from different locations in the town were evaluated for metal element levels. Sixty individuals (study group) who have been drinking water from these sources for a minimum of one year and thirty individuals of the control group were evaluated for cadmium, lead, zinc, copper and sex hormone levels.

\subsection{Research Design}

This is a prospective case-control study of male participants who consumed drinking water from hand dug wells, boreholes, and also drank treated water. Blood samples were collected from participants in the morning.

\subsection{Inclusion and Exclusion Criteria}

Healthy men within the reproductive age of 20-45 years and drank water solely from hand dug wells and consumed borehole water and treated water were included in the study. Individuals on male contraceptives, or with testicular varicocele, had been on long-term medications, living with HIV, or had chronic and serious systemic illness, took steroid preparations, did not consent and were smokers were excluded from the study.

\subsection{Ethical Consideration}

The protocol for the study was reviewed and approved by the Ethics Committee of the Edo State Ministry of Health (ethical code HM1208266, dated 31 July 2017). Informed consent was given by the participants before commencement of study.

\subsection{Data Collection Tools and Techniques}

The socio-demographic data were collected using a semi-structured questionnaire. The questionnaire was distributed among male participants drinking water from hand dug well and borehole water as well as those who consume treated water.

\subsection{Laboratory Analysis}

Estimation of Cadmium, Lead, Zinc and Copper

Procedure

Exactly $1 \mathrm{~mL}$ of whole blood sample was measured and poured into the khedjahl digestion tube, $5 \mathrm{~mL}$ of the mixed acid (Nitric-Perchloric acid mixture. Ratio 2:1) was added. Digestion tube was brought to the heater and heated. When dense white fume occurred, heating continues until a clean solution was obtained. It was removed from the heater, cooled, and a small amount of deionized water was added. The solution was filtered with Whiteman no 42 filter paper into a $25 \mathrm{~mL}$ volumetric flask, and the volume was made up with deionized water to $25 \mathrm{~mL}$. A reagent blank was prepared identically but without the blood sample. The metal concentrations were determined by an Atomic Absorption Spectrophotometer (BUCK Scientific, Norwalk, CT, USA) according to the manufacturer's protocol. 


\subsection{Standard Preparation (QC)}

The AAS was first calibrated using Buck certified atomic absorption standards for the respective metals to obtain a calibration curve. The reagent blank was run at intervals of every 10 samples of analysis to eliminate equipment drift. All samples were analyzed in duplicate for reproducibility, precision and to ensure accurate checks.

\subsection{Determination of Sex Hormones}

The sex hormones (luteinizing hormone, follicle stimulating hormone, prolactin, testosterone, estradiol and progesterone) were assayed by ELISA technique (Monobind Inc. Lake Forest, CA, USA (Accu-Bind ELISA Microwells)).

\subsection{Data Analysis}

Data analysis was done using the statistical software SPSS version 21 (SPSS Inc., Chicago, IL, USA). The Student's $t$-test and Chi-square test were used to compare variables where appropriate, and a $p<0.05$ was considered statistically significant.

\section{Results}

The age distribution of the 90 male subjects in this study shows that a majority $(62.2 \%)$ were between the ages of 18-25 years, while the least $(6.6 \%)$ were 40 years and above; $3.3 \%$ were underweight (BMI of less than $16.5 \mathrm{~kg} / \mathrm{m}^{2}$ ), $35.5 \%$ were overweight (BMI of $28.6 \mathrm{~kg} / \mathrm{m}^{2}$ and $14.4 \%$ were obese (BMI of $33.5 \mathrm{~kg} / \mathrm{m}^{2}$ ) (Table 1 ).

Table 1. Age and body mass index of hand-dug well/borehole water and treated water consumers.

\begin{tabular}{|c|c|c|c|c|c|}
\hline Variables & $\begin{array}{c}\text { Total } \\
(n=90)\end{array}$ & $\begin{array}{l}\text { Dug-Well and Borehole } \\
\text { Water Consumers } \\
\qquad(\mathrm{n}=60)\end{array}$ & $\begin{array}{l}\text { Control Group } \\
\quad(n=30)\end{array}$ & $X^{2}$ & $p$-Value \\
\hline & & Age (Years) & & & \\
\hline $18-25$ & $56(62.2 \%)$ & $31(51.6 \%)$ & $25(83.3 \%)$ & & \\
\hline $26-35$ & $20(22.2 \%)$ & $15(25.0 \%)$ & $5(16.6 \%)$ & & \\
\hline $36-40$ & $8(8.8 \%)$ & $8(13.3 \%)$ & $0(0.0 \%)$ & 71.60 & $p=0.001$ \\
\hline \multirow[t]{2}{*}{ 40-above } & $6(6.6 \%)$ & $6(10.0 \%)$ & $0(0.0 \%)$ & & \\
\hline & & Body mass & Index $\left(\mathrm{kg} / \mathrm{m}^{2}\right)$ & & \\
\hline Underweight & $3(3.3 \%)$ & $3(5.0 \%)$ & $0(0.0 \%)$ & & \\
\hline Normal & $42(46.6 \%)$ & $22(36.6 \%)$ & $20(66.6 \%)$ & & \\
\hline Overweight & $32(35.5 \%)$ & $23(38.6 \%)$ & $9(30.0 \%)$ & 45.53 & $p=0.001$ \\
\hline Obese & $13(14.4 \%)$ & $12(20.0 \%)$ & $1(3.3 \%)$ & & \\
\hline
\end{tabular}

Chi-Square $\left(\mathrm{X}^{2}\right)$ was used to compare the categorical variables.

Table 2 indicates that the concentrations of $\mathrm{Cd}$ and $\mathrm{Pb}$ in hand-dug well and borehole water were higher than the World Health Organization (WHO) permissible limits in drinking water while the concentrations of $\mathrm{Zn}$ and $\mathrm{Cu}$ were within the WHO permissible limits [18].

Table 2. Toxic and essential metal concentrations in hand-dug well, borehole and treated water.

\begin{tabular}{ccccc}
\hline Sources of Water & Toxic and & Essential & Metals & \\
\hline & $\mathrm{Cd}(\mu \mathrm{g} / \mathrm{dL})$ & $\mathrm{Pb}(\mu \mathrm{g} / \mathrm{dL})$ & $\mathrm{Zn}(\mu \mathrm{g} / \mathrm{dL})$ & $\mathrm{Cu}(\mu \mathrm{g} / \mathrm{dL})$ \\
Hand-dug well & $0.51 \pm 0.02$ & $1.81 \pm 0.10$ & $215 \pm 9.8$ & $125 \pm 10.2$ \\
$\quad(\mathrm{n}=10)$ & $0.32 \pm 0.01$ & $1.10 \pm 0.02$ & $198 \pm 10.2$ & $105 \pm 8.2$ \\
$\begin{array}{c}\text { Borehole }(\mathrm{n}=10) \\
\text { Treated water } \\
(\mathrm{n}=10)\end{array}$ & $0.29 \pm 0.01$ & $0.81 \pm 0.10$ & $192 \pm 9.8$ & $104 \pm 7.9$ \\
$\begin{array}{c}\text { WHO permissible limit in } \\
\text { drinking water }\end{array}$ & $0.3(0.003 \mathrm{mg} / \mathrm{L})$ & $1.0(0.010 \mathrm{mg} / \mathrm{L})$ & $300(3.0 \mathrm{mg} / \mathrm{L})$ & $200(2.0 \mathrm{mg} / \mathrm{L})$ \\
\hline
\end{tabular}


The levels of $\mathrm{Cd}$ and $\mathrm{Pb}$ were significantly higher $(p<0.001)$ in hand-dug well and borehole water consumers, while $\mathrm{Zn}$ was significantly lower $(p<0.001)$ in hand dug well/borehole water consumers than treated water consumers (Table 3).

Table 3. Levels of Blood $\mathrm{Cd}, \mathrm{Pb}, \mathrm{Cu}$ and $\mathrm{Zn}$ among Hand-Dug Well/Borehole Water Consumers and treated water consumers.

\begin{tabular}{cccc}
\hline $\begin{array}{c}\text { Measured } \\
\text { Parameters }\end{array}$ & $\begin{array}{c}\text { Hand-Dug } \\
\text { Well/Borehole Water } \\
\text { Consumers } \\
\mathbf{N}=\mathbf{6 0}\end{array}$ & $\begin{array}{c}\text { Treated Water } \\
\text { Consumers } \\
\mathbf{N}=\mathbf{3 0}\end{array}$ & $p$-Value \\
\hline $\mathrm{Cd}(\mu \mathrm{g} / \mathrm{dL})$ & $3.62 \pm 0.41$ & $0.91 \pm 0.21$ & $p=0.001$ \\
$\mathrm{~Pb}(\mu \mathrm{g} / \mathrm{dL})$ & $3.89 \pm 3.25$ & $1.64 \pm 0.04$ & $p=0.001$ \\
$\mathrm{Cu}(\mu \mathrm{g} / \mathrm{dL})$ & $97.03 \pm 1.62$ & $97.90 \pm 2.63$ & $p=0.335$ \\
$\mathrm{Zn}(\mu \mathrm{g} / \mathrm{dL})$ & $98.26 \pm 2.58$ & $163.30 \pm 3.43$ & $p=0.001$ \\
\hline Value are expressed in mean \pm SD, Cd-cadmium, Pb-lead, Cu-Copper, Zn-Zinc. $p<0.05$-Significant.
\end{tabular}

The comparison of blood $\mathrm{Cd}, \mathrm{Pb}, \mathrm{Cu}$ and $\mathrm{Zn}$ among consumers of hand-dug well water and borehole water shows that $\mathrm{Cd}$ and $\mathrm{Pb}$ were significantly higher $(p<0.001)$ among hand-dug well water consumers than borehole water consumers while $\mathrm{Cu}$ and $\mathrm{Zn}$ were significantly lower in hand-dug well water consumers than borehole water consumers (Table 4).

Table 4. Comparison of Blood $\mathrm{Cd}, \mathrm{Pb}$, serum $\mathrm{Cu}$ and $\mathrm{Zn}$ levels in Hand-dug Well and Borehole Water Consumers.

\begin{tabular}{cccc}
\hline $\begin{array}{c}\text { Measured } \\
\text { Parameters }\end{array}$ & $\begin{array}{c}\text { Hand-Dug Well Water } \\
\text { Consumers } \\
\mathbf{N}=\mathbf{3 0}\end{array}$ & $\begin{array}{c}\text { Borehole Water } \\
\text { Consumers } \\
\mathbf{N}=\mathbf{3 0}\end{array}$ & $p$-Value \\
\hline $\mathrm{Cd}(\mu \mathrm{g} / \mathrm{dL})$ & $3.61 \pm 0.55$ & $2.66 \pm 0.21$ & $p=0.001$ \\
$\mathrm{~Pb}(\mu \mathrm{g} / \mathrm{dL})$ & $4.00 \pm 0.26$ & $2.08 \pm 0.42$ & $p=0.001$ \\
$\mathrm{Cu}(\mu \mathrm{g} / \mathrm{dL})$ & $91.08 \pm 1.41$ & $106.70 \pm 4.41$ & $p=0.001$ \\
$\mathrm{Zn}(\mu \mathrm{g} / \mathrm{dL})$ & $97.25 \pm 2.16$ & $116.95 \pm 4.58$ & $p=0.001$ \\
\hline
\end{tabular}

Values are expressed in mean $\pm \mathrm{SD}$; Cd-cadmium, Pb-lead, Cu-Copper, Zn-Zinc. $p<0.05$-Significant.

Table 5 shows that serum FSH $(p<0.001)$, LH $(p<0.001)$, estradiol $(p<0.002)$, progesterone $(p<0.04)$, and testosterone $(p<0.001)$ were significantly lower among hand-dug well/borehole water consumers than treated water consumers. Conversely, serum prolactin was significantly higher $(p<0.001)$ among hand-dug well/borehole water consumers than treated water consumers. Serum FSH, LH, estradiol, testosterone and prolactin were significantly lower $(p<0.001)$ among hand-dug water consumers than borehole water consumers (Table 6).

Table 5. Comparison of serum sex Hormone levels among Hand-dug Well/Borehole Water Consumers and Treated water consumers.

\begin{tabular}{cccc}
\hline $\begin{array}{c}\text { Measured } \\
\text { Parameters }\end{array}$ & $\begin{array}{c}\text { Hand-Dug } \\
\text { Well/Borehole Water } \\
\text { Consumers } \\
\mathbf{N}=\mathbf{6 0}\end{array}$ & $\begin{array}{c}\text { Treated Water } \\
\text { Consumers } \\
\mathbf{N}=\mathbf{3 0}\end{array}$ & $\boldsymbol{p}$-Value \\
\hline FSH $(\mathrm{miu} / \mathrm{mL})$ & $3.26 \pm 0.33$ & $5.83 \pm 0.38$ & $p=0.001$ \\
LH $(\mathrm{miu} / \mathrm{mL})$ & $1.46 \pm 0.14$ & $6.98 \pm 0.28$ & $p=0.001$ \\
E2 $(\mathrm{pg} / \mathrm{mL})$ & $2.63 \pm 0.33$ & $9.93 \pm 2.26$ & $p=0.002$ \\
PROG $(\mathrm{ng} / \mathrm{mL})$ & $1.34 \pm 0.41$ & $4.11 \pm 1.29$ & $p=0.04$ \\
T $(\mathrm{ng} / \mathrm{mL})$ & $3.68 \pm 0.30$ & $6.54 \pm 0.27$ & $p=0.001$ \\
PROL $(\mathrm{ng} / \mathrm{mL})$ & $22.07 \pm 0.66$ & $18.37 \pm 0.49$ & $p=0.001$ \\
\hline
\end{tabular}

Values are expressed in mean \pm SD; FSH-follicle stimulating hormone, LH-Luteinizing hormone, $\mathrm{E}_{2}$-Estradiol, Prog-Progesterone, T-Testosterone, Prol-Prolactin. $p<0.05$-Significant. 
Table 6. Serum Hormone Levels among Hand-Dug Well and Borehole Water Consumers.

\begin{tabular}{cccc}
\hline $\begin{array}{c}\text { Measured } \\
\text { Parameters }\end{array}$ & $\begin{array}{c}\text { Hand-Dug Well Water } \\
\text { Consumers } \\
\mathbf{N}=\mathbf{3 0}\end{array}$ & $\begin{array}{c}\text { Borehole Water } \\
\text { Consumers } \\
\mathbf{N}=\mathbf{3 0}\end{array}$ & $p$-Value \\
\hline FSH $(\mathrm{miu} / \mathrm{mL})$ & $1.92 \pm 0.23$ & $4.72 \pm 0.74$ & $p=0.001$ \\
LH $(\mathrm{miu} / \mathrm{mL})$ & $1.10 \pm 0.11$ & $2.21 \pm 0.30$ & $p=0.001$ \\
E $_{2}(\mathrm{pg} / \mathrm{mL})$ & $1.32 \pm 0.27$ & $4.38 \pm 0.64$ & $p=0.001$ \\
PROG $(\mathrm{ng} / \mathrm{mL})$ & $0.91 \pm 0.27$ & $1.93 \pm 0.10$ & $p=0.244$ \\
T $(\mathrm{ng} / \mathrm{mL})$ & $2.79 \pm 0.16$ & $4.98 \pm 0.36$ & $p=0.001$ \\
PROL $(\mathrm{ng} / \mathrm{mL})$ & $19.80 \pm 0.76$ & $25.85 \pm 0.67$ & $p=0.001$ \\
\hline
\end{tabular}

Value are expressed in mean \pm SD. FSH $=$ follicle stimulating hormone, $\mathrm{LH}=$ Luteinizing hormone, $\mathrm{E}_{2}=$ Estradiol, Prog $=$ Progesterone, $\mathrm{T}=$ Testosterone, Prol $=$ Prolactin. $p<0.05-$ Significant.

Table 7 shows the interrelationship of FSH and LH with toxic and essential metals, age and BMI of participants. Serum FSH correlated negatively $(\mathrm{r}=-0.398 ; p<0.001)$ with $\mathrm{Pb}$, and positively with serum $\mathrm{Zn}(\mathrm{r}=0.422 ; p<0.002)$. Similarly, LH correlated negatively with $\mathrm{Cd}(\mathrm{r}=-0.622 ; p<0.001)$ and positively with $\mathrm{Zn}(\mathrm{r}=0.745 ; p<0.001)$. No significant correlation was observed between FSH, LH and the other measured variables. The regression coefficient between serum estradiol and other measured parameters indicates that estradiol correlated positively with $\mathrm{Zn}(\mathrm{r}=0.412 ; p<0.003)$. There was no significant correlation between serum progesterone and other measured parameters. Similarly, serum prolactin correlated positively with $\mathrm{Pb}(\mathrm{r}=0.443 ; p<0.006)$ and negatively with $\mathrm{Zn}(\mathrm{r}=-404 ; p<0.047)$. Lastly, serum testosterone correlated positively with $\mathrm{Zn}(\mathrm{r}=0.542$; $p<0.001$ ) (Tables 8 and 9).

Table 7. Interrelationship of sex hormones and other measured indices.

\begin{tabular}{|c|c|c|c|c|c|}
\hline Variables & $\mathbf{N}$ & $\begin{array}{c}\text { Regression } \\
\text { Coefficient }(\beta)\end{array}$ & $\begin{array}{l}\text { Standard Error of } \\
\text { Coefficient }(\beta)\end{array}$ & $\begin{array}{l}\text { Pearson Correlation } \\
\text { Coefficient (r) }\end{array}$ & $p$-Value \\
\hline \multicolumn{6}{|l|}{$\mathrm{FSH}(\mathrm{miu} / \mathrm{mL})$} \\
\hline $\mathrm{Cd}(\mu \mathrm{g} / \mathrm{L})$ & 60 & 0.067 & 0.096 & -0.275 & 0.606 \\
\hline $\mathrm{Pb}(\mu \mathrm{g} / \mathrm{L})$ & 60 & -0.260 & 0.019 & -0.398 & $0.045^{* *}$ \\
\hline $\mathrm{Cu}(\mu \mathrm{g} / \mathrm{dL})$ & 60 & -0.018 & 0.022 & 0.055 & 0.863 \\
\hline $\mathrm{Zn}(\mu \mathrm{g} / \mathrm{dL})$ & 60 & 0.304 & 0.005 & 0.422 & $0.0021^{* *}$ \\
\hline Age (years) & 60 & 0.009 & 0.360 & -0.015 & 0.930 \\
\hline BMI $\left(\mathrm{kg} / \mathrm{m}^{2}\right)$ & 60 & -0.062 & 0.064 & -0.172 & 0.550 \\
\hline \multicolumn{6}{|l|}{$\mathrm{LH}(\mathrm{miu} / \mathrm{mL})$} \\
\hline $\mathrm{Cd}(\mu \mathrm{g} / \mathrm{L})$ & 60 & -0.266 & 0.072 & -0.622 & $0.005^{* *}$ \\
\hline $\mathrm{Pb}(\mu \mathrm{g} / \mathrm{L})$ & 60 & -0.038 & 0.014 & -0.493 & 0.674 \\
\hline $\mathrm{Cu}(\mu \mathrm{g} / \mathrm{dL})$ & 60 & -0.055 & 0.016 & 0.033 & 0.452 \\
\hline $\mathrm{Zn}(\mu \mathrm{g} / \mathrm{dL})$ & 60 & 0.573 & 0.004 & 0.745 & $0.001^{* *}$ \\
\hline Age (years) & 60 & -0.034 & 0.027 & -0.068 & 0.630 \\
\hline BMI $\left(\mathrm{kg} / \mathrm{m}^{2}\right)$ & 60 & 0.022 & 0.648 & -0.205 & 0.765 \\
\hline
\end{tabular}

$\mathrm{FSH}=$ Follicle stimulating hormone, $\mathrm{LH}=$ Luteinizing hormone, $\mathrm{E}_{2}=$ Estradiol $, \mathrm{Cd}=\mathrm{Cadmium}, \mathrm{Pb}=\mathrm{Lead}$ $\mathrm{Cu}=$ Copper, $\mathrm{Zn}=$ Zinc, $\mathrm{BMI}=$ Body mass index, $\mathrm{PROG}=$ Progesterone, $\mathrm{PROL}=$ Prolactin, $\mathrm{TESTO}=$ Testosterone ** Significant (Pearson Correlation). 
Table 8. Interrelationship of sex hormones with other measured indices.

\begin{tabular}{|c|c|c|c|c|c|}
\hline Variables & $\mathbf{N}$ & $\begin{array}{c}\text { Regression } \\
\text { Coefficient }(\beta)\end{array}$ & $\begin{array}{l}\text { Standard Error of } \\
\text { Coefficient }(\beta)\end{array}$ & $\begin{array}{l}\text { Pearson Correlation } \\
\text { Coefficient (r) }\end{array}$ & $p$-Value \\
\hline \multicolumn{6}{|l|}{$\mathrm{E}_{2}(\mathrm{pg} / \mathrm{L})$} \\
\hline $\mathrm{Cd}(\mu \mathrm{g} / \mathrm{L})$ & 60 & 0.066 & 0.287 & -0.230 & 0.622 \\
\hline $\mathrm{Pb}(\mu \mathrm{g} / \mathrm{L})$ & 60 & -0.026 & 0.057 & -0.250 & 0.840 \\
\hline $\mathrm{Cu}(\mu \mathrm{g} / \mathrm{dL})$ & 60 & 0.040 & 0.065 & 0.065 & 0.703 \\
\hline $\mathrm{Zn}(\mu \mathrm{g} / \mathrm{dL})$ & 60 & -0.399 & 0.016 & 0.412 & $0.003^{* *}$ \\
\hline Age (years) & 60 & -0.041 & 0.107 & -0.041 & 0.687 \\
\hline $\mathrm{BMI}\left(\mathrm{kg} / \mathrm{m}^{2}\right)$ & 60 & -0.131 & 0.191 & -0.268 & 0.223 \\
\hline \multicolumn{6}{|l|}{ PROG (ng/mL) } \\
\hline $\mathrm{Cd}(\mu \mathrm{g} / \mathrm{L})$ & 60 & -0.170 & 0.183 & -0.222 & 0.229 \\
\hline $\mathrm{Pb}(\mu \mathrm{g} / \mathrm{L})$ & 60 & 0.147 & 0.036 & -0.055 & 0.287 \\
\hline $\mathrm{Cu}(\mu \mathrm{g} / \mathrm{dL})$ & 60 & -0.075 & 0.041 & -0.087 & 0.499 \\
\hline $\mathrm{Zn}(\mu \mathrm{g} / \mathrm{dL})$ & 60 & -0.192 & 0.010 & 0.229 & 0.172 \\
\hline Age(years) & 60 & -0.022 & 0.068 & 0.004 & 0.841 \\
\hline BMI $\left(\mathrm{kg} / \mathrm{m}^{2}\right)$ & 60 & -0.036 & 0.081 & -0.102 & 0.661 \\
\hline
\end{tabular}

$\mathrm{FSH}=$ Follicle stimulating hormone, $\mathrm{LH}=$ Luteinizing hormone, $\mathrm{E}_{2}=$ Estradiol, $\mathrm{Cd}=$ Cadmium, $\mathrm{Pb}=\mathrm{Lead}$ $\mathrm{Cu}=$ Copper, $\mathrm{Zn}=$ Zinc, $\mathrm{BMI}=$ Body mass index, $\mathrm{PROG}=$ Progesterone, $\mathrm{PROL}=$ Prolactin, $\mathrm{TESTO}=$ Testosterone ** Significant (Pearson Correlation).

Table 9. Interrelationship of sex hormones with other measured parameters.

\begin{tabular}{|c|c|c|c|c|c|}
\hline Variables & $\mathbf{N}$ & $\begin{array}{c}\text { Regression } \\
\text { Coefficient }(\beta)\end{array}$ & $\begin{array}{l}\text { Standard Error of } \\
\text { Coefficient }(\beta)\end{array}$ & $\begin{array}{l}\text { Pearson Correlation } \\
\text { Coefficient (r) }\end{array}$ & $p$-Value \\
\hline \multicolumn{6}{|l|}{ PROL (ng/mL) } \\
\hline $\mathrm{Cd}(\mu \mathrm{g} / \mathrm{L})$ & 60 & -0.053 & 0.160 & 0.282 & 0.679 \\
\hline $\mathrm{Pb}(\mu \mathrm{g} / \mathrm{L})$ & 60 & 0.354 & 0.032 & 0.443 & $0.006^{* *}$ \\
\hline $\mathrm{Cu}(\mu \mathrm{g} / \mathrm{dL})$ & 60 & 0.093 & 0.036 & -0.024 & 0.356 \\
\hline $\mathrm{Zn}(\mu \mathrm{g} / \mathrm{dL})$ & 60 & -0.257 & 0.009 & -0.404 & $0.047^{* *}$ \\
\hline Age (years) & 60 & 0.061 & 0.060 & 0.098 & 0.654 \\
\hline BMI $\left(\mathrm{kg} / \mathrm{m}^{2}\right)$ & 60 & -0.046 & 0.106 & 0.072 & 0.654 \\
\hline \multicolumn{6}{|l|}{ TESTO (ng/mL) } \\
\hline $\mathrm{Cd}(\mu \mathrm{g} / \mathrm{L})$ & 60 & -0.132 & 0.087 & -0.426 & 0.280 \\
\hline $\mathrm{Pb}(\mu \mathrm{g} / \mathrm{L})$ & 60 & -0.105 & 0.017 & -0.400 & 0.382 \\
\hline $\mathrm{Cu}(\mu \mathrm{g} / \mathrm{dL})$ & 60 & -0.005 & 0.020 & 0.072 & 0.961 \\
\hline $\mathrm{Zn}(\mu \mathrm{g} / \mathrm{dL})$ & 60 & 0.418 & 0.005 & 0.542 & $0.001^{* *}$ \\
\hline Age (years) & 60 & 0.006 & 0.033 & -0.035 & 0.949 \\
\hline BMI $\left(\mathrm{kg} / \mathrm{m}^{2}\right)$ & 60 & 0.054 & 0.058 & -0.109 & 0.580 \\
\hline
\end{tabular}

$\mathrm{FSH}=$ Follicle stimulating hormone, $\mathrm{LH}=$ Luteinizing hormone, $\mathrm{E}_{2}=$ Estradiol, $\mathrm{Cd}=$ Cadmium, $\mathrm{Pb}=\mathrm{Lead}$ $\mathrm{Cu}=$ Copper, $\mathrm{Zn}=$ Zinc, $\mathrm{BMI}=$ Body mass index, $\mathrm{PROG}=$ Progesterone, $\mathrm{PROL}=$ Prolactin, $\mathrm{TESTO}=$ Testosterone ** Significant (Pearson Correlation).

\section{Discussion}

Toxic metal contamination in drinking water is a potential health risk to humans and has been reported to be one of the root causes of many chronic health challenges, including cancer, infertility, and organ damage [25]. The presence of toxic metals and trace elements cannot be visualized with the naked eye, but are detected in water through laboratory tests. This study was conducted to determine $\mathrm{Cd}, \mathrm{Pb}, \mathrm{Zn}$ and $\mathrm{Cu}$ levels in hand-dug well, borehole and treated drinking water and the possible reproductive health effects on the consumers. In order to protect human health, guidelines for the presence of toxic metals and trace elements in drinking water have been given by international organizations such as the WHO and the European Union Commission [26]. These organizations prescribed that these chemical element levels in water should not be higher than the maximum permissible level in the water as specified. Maximum contaminant level is an enforceable standard in numerical range value to ensure no adverse effects on human health. The upper limit of the 
highest level of a contaminant is the maximum allowed in a water system for a particular chemical element.

The concentrations of $\mathrm{Cd}$ and $\mathrm{Pb}$ in hand-dug well and borehole water were higher than WHO-recommended permissible limits in drinking water [27]. This is consistent with previous studies in some parts of Nigeria. For example, Momodu and Anyakora [28] observed that $84.21 \%$ of underground water samples contained Cd concentrations higher than the maximum contaminant level $(0.003 \mathrm{mg} / \mathrm{L})$, with maximum concentrations of $0.098 \mathrm{mg} / \mathrm{L}(9.8 \mu \mathrm{g} / \mathrm{dL})$. The reported concentration is higher than observed in this study $(0.56 \mu \mathrm{g} / \mathrm{dL})$. The detected level, which is higher than the maximum contaminant level, is of great concern, since Cd has the potential to cause male infertility [29], cancers [30], because of its long biological half-life [31], and it can bioaccumulate, leading to chronic organ damage [32].

The concentration of $\mathrm{Pb}$ detected in hand-dug well and borehole water in this study was also higher than the recommended permissible limit by WHO. The finding is consistent with that of Momodu and Anyakara [28] in Surulere, Lagos. The authors observed that 10 of the well water samples and 19 borehole water samples contained $\mathrm{Pb}$, and six of the well water samples and 12 of the borehole water samples contained levels above the maximum contaminant level $(0.01 \mathrm{mg} / \mathrm{L})$, with the maximum concentration detected being $0.024 \mathrm{mg} / \mathrm{L}(2.4 \mu \mathrm{g} / \mathrm{dL})$. These findings are of concern, since Pb can bioaccumulate, and it affects the body's general metabolism [33], as well as male infertility [34]. Lead is also a neurotoxin and may be responsible for the most common type of human mental toxicosis [35]. Also, some authors have associated $\mathrm{Pb}$ exposures, even at low levels, with elevated blood pressure [36] and reduced intelligence quotients in children [37]. Lead is a naturally occurring metal present in small quantities in the Earth's crust. Although lead occurs naturally in the environment, human activities such as the use of fossil fuel, mining and manufacturing industries contribute to the release of high concentrations of it. The concentration of $\mathrm{Pb}$ observed in hand-dug well and borehole water was higher than in treated water and more than the quantity recommended in drinking water by the WHO. The permissible limit recommended by WHO for drinking water is $0.01 \mathrm{mg} / \mathrm{L}$. It has been emphasized that chemical contaminants in drinking water is a public health risk and may have immediate health effects [38]. These contaminants commonly occur due to natural and anthropogenic activities [39]. Natural sources of contaminants include host rocks which may be due to the geology of the area, volcanic activities, and chemical evolution, while anthropogenic activities commonly emanate from indiscriminate disposal of waste, urbanization, industrialization, mining and domestic activities, among others $[40,41]$. Some of the described mechanisms by which toxic metals impair reproductive health are ion mimicry, disruption of cell signaling pathways, epigenetic control of gene expression, oxidative stress, apoptosis, altered gene expression, inflammation, damaging of the testis-blood barrier and endocrine disruption. The relatively high levels of toxic metals in hand-dug wells and borehole drinking water may pose some reproductive health challenges. Apart from the observed abnormal levels of sex hormones in the participants, some authors have reported significantly higher levels of $\mathrm{Cd}$ and $\mathrm{Pb}$ in seminal plasma as well as poor semen quality among infertile men [29,34]. Female reproductive health is also affected by toxic metal accumulation. Cadmium has been reported to accumulate in human endometrial tissue, and can stimulate estrogen production by binding with alpha and beta estrogen receptors, as well as progesterone receptors, leading to estrogen dependent diseases (breast and endometrial cancers, endometriosis and spontaneous abortions). Similarly, toxic metal accumulation in children have been associated with mental retardation, neurocognitive disorders, behavioural disorders, respiratory diseases, cancer and cardiovascular diseases $[6,19,21,42]$.

The significantly lower levels of $\mathrm{Zn}$ and $\mathrm{Cu}$ in those who drink hand-dug well and borehole water than control subjects may be due to the interaction of between $\mathrm{Cd}$ and essential elements. This interaction occurs at different stages of absorption, distribution in 
the body, and excretion of the elements at the stage of biological functions. Therefore, the zinc status of the body is especially vital in relation to accumulation of $\mathrm{Cd}$ in the body.

In this study, it was observed that the concentrations of $\mathrm{Pb}$ and $\mathrm{Cd}$ in the blood of hand dug well and borehole water consumers were higher than those consuming treated water in the same environment (controls). This finding is consistent with the other studies in Baghdad, Beirut, and Al-Najaf, which reported that the blood $\mathrm{Pb}$ and other toxic metals were higher among exposed individuals [43,44]. Copper and zinc were lower in the subject than the controls. The higher blood level of $\mathrm{Cd}$ and $\mathrm{Pb}$ among the subjects may be traceable to the drinking of contaminated water (hand-dug well and borehole water) since the respondents were non-occupationally exposed. The respondents reported that they have been consuming water from these sources for several years, it being the only source of drinking water during the study.

Significantly lower levels of sex hormones among the subjects that consume hand-dug well and borehole water than controls were also observed. From previous studies, it was observed that toxic metal contaminations are potent endocrine disruptors and oxidative stress inducers [45] as well as hypothalamo-pituitary-gonadal axis inhibitors [46-48]. These glands have been shown to act with a common function in order to achieve a common goal of regulating the reproductive and sex hormone production. The HPG axis plays a critical part in the development and regulation of a number of the body's systems, such as the reproductive and immune systems. Any fluctuations in this axis causes changes in the hormones produced by each gland and has various local and systemic effects on the body. This axis controls development, reproduction and ageing in animals [49]. Gonadotropin-releasing hormone $(\mathrm{GnRH})$ is secreted from the hypothalamus by GnRH-expressing neurons. The anterior portion of the pituitary gland produces luteinizing hormone (LH) and follicle stimulating hormone (FSH) and the gonads produce estrogen and testosterone. The male reproductive system depends upon the activities of these different hormones produced by various body glands for adequate physiological functions [50]. Testosterone helps to produce and maintain the secondary sexual characteristics of the male and is also responsible for the sex drive as well as work with the FSH to stimulate the production of sperm. If the sperm levels are high, the testes release inhibin which travels through the blood stream to the brain, where it prevents the secretion of GnRH. In the absence of GnRH, FSH, and LH levels fall and sperm production slows. This is one of the major feedback mechanisms which help to regulate and maintained sex hormones at relatively constant concentrations [51].

The data indicate that lead $(\mathrm{Pb})$ was negatively associated with FSH and Estradiol and cadmium was negatively associated with LH. This result is in line with the study carried out by Telisman et al. [52]. Conversely, zinc correlated positively with FSH, LH, Estradiol and testosterone and negatively correlated $(p<0.05)$. Therefore, the observed decline in the serum levels of the reproductive hormones with increased levels of toxic metals suggests that toxic metals may have been responsible for the significantly lower levels of the hormones.

\section{Conclusions}

From this study, it is evident that consumption of contaminated water with toxic metals might pose a reproductive health threat to consumers. This alteration in reproductive hormone levels may cause subfertility and other disease conditions in men. In view of the dangers associated with the consumption of water contaminated with toxic metals and other impurities, it becomes necessary to ensure that water from hand-dug wells and boreholes should be treated before consumption. Such methods of water purification include physical methods (filtration, sedimentation or boiling and distillation), biological methods (sand filters, active carbon) and chemical methods (flocculation, chlorination and the use of ultraviolet light). 
Author Contributions: This work was conducted and approved in collaboration between all the authors. M.A.E. designed the study; O.O.E. sourced for funding; M.A.E. and O.O.E. wrote the protocol; O.O.E. contributed in literature search; O.O.E. did the experiments; O.O.E. and M.A.E. did statistical analysis; O.O.E. drafted the manuscript; M.A.E. supervised the study; M.A.E. Wrote the final manuscript; M.A.E. proofread the manuscript. All authors have read and agreed to the published version of the manuscript.

Funding: This research received no external funding.

Institutional Review Board Statement: The study was conducted in accordance with the Declaration of Helsinki, and approved by the Edo State Ministry of Health Ethics Committee (HM1208266, dated 31 July 2017).

Informed Consent Statement: Informed consent was obtained from all subjects involved in the study.

Data Availability Statement: Data from MSc project conducted at the Department of Medical Laboratory Science, University of Benin, Benin City, Nigeria.

Conflicts of Interest: The authors declare no conflict of interest.

\begin{tabular}{ll}
\multicolumn{2}{l}{ Abbreviations } \\
$\mathrm{Pb}$ & lead \\
$\mathrm{Cd}$ & Cadmium \\
$\mathrm{Zn}$ & Zinc \\
$\mathrm{Cu}$ & Copper \\
$\mathrm{FSH}$ & Follicle Stimulating Hormone \\
$\mathrm{LH}$ & Luteinizing hormone \\
$\mathrm{PROL}$ & Prolactin \\
$\mathrm{PROG}$ & Progesterone \\
$\mathrm{E}_{2}$ & Estradiol \\
$\mathrm{T}$ & Testosterone \\
$\mathrm{GnRH}$ & Gonadotropin-Releasing hormone \\
$\mathrm{HPG}$ & Hypothalamic-Pituitary-Gonadal
\end{tabular}

\section{References}

1. Landrigan, P.J.; Fuller, R.; Acosta, N.J.R.; Adeyi, O.; Arnold, R.; Basu, N.N.; Baldé, A.B.; Bertollini, R.; Bose-O’Reilly, S.; Boufford, J.I.; et al. The Lancet Commission on pollution and health. Lancet 2018, 391, 462-512. [CrossRef]

2. Appannagari, R.R.R. Environmental Pollution Causes and Consequences: A Study. Project: Environment and Ecology. North Asian Int. Res. J. Soc. Sci. Humanit. 2017, 3, 151-161.

3. Ghassabian, A.; Trasande, L. Disruption in Thyroid Signaling Pathway: A Mechanism for the Effect of Endocrine-Disrupting Chemicals on Child Neurodevelopment. Front. Endocrinol. 2018, 9, 204. [CrossRef]

4. Kim, M.J.; Park, Y.J. Bisphenols and Thyroid Hormone. Endocrinol. Metab. 2019, 34, 340-348. [CrossRef]

5. Giera, S.; Bansal, R.; Ortiz-Toro, T.M.; Taub, D.G.; Zoeller, R.T. Individual polychlorinated biphenyl (PCB) congeners produce tissue- and gene-specific effects on thyroid hormone signaling during development. Endocrinology 2011, 152, 2909-2919. [CrossRef]

6. Graceli, J.B.; Dettogni, R.S.; Merlo, E.; Niño, O.; da Costa, C.S.; Zanol, J.F.; Ríos-Morris, E.A.; Miranda-Alves, L.; Denicol, A.C. The impact of endocrine-disrupting chemical exposure in the mammalian hypothalamic-pituitary axis. Mol. Cell Endocrinol. 2020, 518, 110997. [CrossRef]

7. Zhang, X.; Cui, S.; Pan, L.; Dong, W.; Ma, M.; Liu, W.; Zhuang, S. The molecular mechanism of the antagonistic activity of hydroxylated polybrominated biphenyl (OH-BB80) toward thyroid receptor. Sci. Total Environ. 2019, 697, 134040. [CrossRef]

8. Vanderpump, M. Epidemiology of Thyroid Disorders. The Thyroid and Its Disease: A Comprehensive Guide for the Clinician; Springer Nature: Berlin/Heidelberg, Germany, 2019; pp. 75-85.

9. Roman, B.R.; Morris, L.G.; Davies, L. The thyroid cancer epidemic, 2017 perspective. Curr. Opin. Endocrinol. Diabetes Obes. 2017, 24, 332-336. [CrossRef]

10. Haugen, B.R.; Alexander, E.K.; Bible, K.C.; Doherty, G.M.; Mandel, S.J.; Nikiforov, Y.E.; Pacini, F.; Randolph, G.W.; Sawka, A.M.; Schlumberger, M.; et al. 2015 American Thyroid Association Management Guidelines for Adult Patients with Thyroid Nodules and Differentiated Thyroid Cancer: The American Thyroid Association Guidelines Task Force on Thyroid Nodules and Differentiated Thyroid Cancer. Thyroid 2016, 26, 1-133. [CrossRef]

11. Vidovix, T.B.; Januário, E.F.D.; Bergamasco, R.; Vieira, A.M.S. Bisfenol A adsorption using a low-cost adsorbent prepared from residues of babassu coconut peels. Environ. Technol. 2021, 42, 2372-2384. [CrossRef] 
12. Mishra, S.; Martin, L.; Lalumière, R.; Williams, J. Personality and Individual Differences; BPS Blackwell: England, UK, 2010; pp. 616-621.

13. Harvey, P.J.; Handley, H.K.; Taylor, M.P. Identification of the sources of metal (lead) contamination in drinking waters in northeastern Tasmania using lead isotopic Compositions. Environ. Sci. Poll. Res. 2015, 22, 12276-12288. [CrossRef]

14. Pezzarossa, B.; Gorini, F.; Petruzelli, G. Heavy Metal and Selenium Distribution and Bioavailability in Contaminated Sites. A Tool for Phytoremediation. In Dynamics and Bioavailability of Heavy Metals in the Rootzone; Selim, H.M., Ed.; CRC Press: Boca Raton, FL, USA, 2011; pp. 93-128.

15. Landis, W.G.; Sofield, R.M.; Yu, M.-H. Introduction to Environmental Toxicology: Molecular Substructures to Ecological Landscapes, 4th ed.; CRC Press: Boca Raton, FL, USA, 2000.

16. Hassan, H.; Sade, A.B.; Muhammad, S.B. Hypermarket retailing expansion as a hub of socio-economic development in Malaysia. J. Bus. Dev. Nations 2015, 14, 33-49.

17. Nardia, P.; Fábio, S.; Evangelist, A.B.; Luciano, T.B.; Tatiana, D.; Saint'Pierre, B.; Adilson, J.; Curtius, B.; Samuel, S.; deSouzaa, F.B The use of inductively coupled plasma mass spectrometry (ICP-MS) for the determination of toxic and essential elements in different types of food samples. Food Chem. 2009, 112, 727-732. [CrossRef]

18. World Health Organization. Guidelines for Drinking-Water Quality, 4th ed.; World Health Organization: Geneva, Switzerland, 2000; Available online: http://www.who.int/about/licensing/copyright_form/en/index.html (accessed on 22 February 2019).

19. Sharma, P.; Dubey, A.; Chatterjee, S.K. Determination of heavy metals in surface and ground water in an around (Agrang Block) Raipur District, Chhattisgarh, India. Int. J. Scientific. Eng. Res. 2013, 4, 722-724.

20. Uadia, P.O.; Emokpae, M.A. Male infertility in Nigeria: A neglected Reproductive Health issue requiring attention. J. Basic. Clin. Reprod. Scis. 2015, 4, 45-53.

21. Emokpae, M.A.; Brown, S.I. Effects of Lifestyle Factors on Fertility: Practical Recommendations for Modification. Reprod. Fertil. 2021, 2, R13-R26. [CrossRef]

22. Moronkeji, M.A.; Emokpae, M.A.; Ojo, T.A.; Moronkeji, R.E.; Ogundoju, L.T. The Patterns and Occupational Distribution of hormonal Abnormalities among men investigated for Infertility in some centers in the Southwest, Nigeria. J. Clin. Transl. Res. 2021, 7, 113-120.

23. Lwanga, S.K.; Lemeshow, S. Sample Size Determination in Health Studies: A Practical Manual; World Health Organization: Geneva, Switzerland, 1991.

24. Emokpae, M.A.; Oyakhire, F.O. Levels of some reproductive hormones, cadmium and lead among fuel pump attendants in Benin City, Nigeria. Afri. J. Med. Health Sci. 2020, 19, 70-77.

25. Atsdr, U.S. Agency for Toxic Substances and Disease Registry (ATSDR). Toxicol. Profiles. Toxic. Subst. 2015, 44, 7-9.

26. Marcovecchio, J.E.; Botte, S.E.; Freije, R.H. Heavy Metals, Major Metals, Trace Elements. In Handbook of Water Analysis, 2nd ed.; Nollet, L.M., Ed.; CRC Press: London, UK, 2007; pp. 275-311.

27. World Health Organization. Hazardous Chemicals in Human and Environmental Health: A Resource Book for School, College and University Students; World Health Organization: Geneva, Switzerland, 2000.

28. Momodu, M.A.; Anyakara, C.A. Heavy Metal Contamination of Ground Water: The Surulere Case Study. Res. J. Environ. Earth Scis. 2010, 2, 39-43.

29. Emokpae, M.A.; Adobor, C.A. Association of seminal plasma cadmium levels with semen quality in non-occupationally exposed infertile Nigerian males. J. Environ. Occup. Scis. 2015, 3, 40-43. [CrossRef]

30. Lauwerys, R.R. Health Effects of Cadmium. In Trace Metal: Exposure and Health Effects; Ferrante, E.D., Ed.; Pergamon Press: England, UK, 1979; pp. 43-64.

31. Orisakwe, O.E.; Igwilo, I.O.; Afonne, O.J.; Maduabuchi, J.U.; Obi, E.; Nduka, J.C. Heavy metal hazards of sachet water in Nigeria. Arch. Environ. Occup. Health 2006, 61, 209-213. [CrossRef]

32. Hammer, M.J.; Hammer Junior, M.J. Water Quality. In Water and Waste Water Technology, 5th ed.; Prentice-Hall: Hoboken, NJ, USA, 2004; pp. 139-159.

33. Adepoju-Bello, A.A.; Alabi, O.M. Heavy metals: A review. The. Nig. J. Pharm. 2005, 37, 41-45.

34. Emokpae, M.A.; Adobor, C.; Ibadin, K. Seminal Plasma levels of lead and mercury in infertile males in Benin City, Nigeria. Int. J. Med. Res. Health Scis. 2016, 5, 1-6. [CrossRef]

35. Berman, E. Toxic Metals and Their Analysis. Philadelphia, PA: Hayden and Sons; Cornell University: New York, NY, USA, 1980; pp. 5-20.

36. Zietz, B.P.; Lap, J.; Suchenwirth, J.R. Assessment and management of tap-water Lead contamination in Lower Saxon, Germany. Int. J. Environ. Health Res. 2007, 17, 407-418. [CrossRef]

37. Needleman, H.L. The current status of childhood low-level lead toxicity. Neurotoxicology 1993, 14, 161-166.

38. Yousefi, M.; Saleh, H.N.; Mohammadi, A.A.; Mahvi, A.H.; Ghadrpoori, M.; Suleimani, H. Data on water quality index for the ground-water in rural area Neyshabur county, Razavi province. Iran. Data Brief 2017, 15, 901-907. [CrossRef]

39. Obasi, P.N.; Akudinobi, B.B. Potential health risk and levels of heavy metals in water resources of lead-zinc mining communities of Abakaliki, southeast Nigeria. Appl. Water Sci. 2020, 10, 184. [CrossRef]

40. Agency for Toxic Substances and Disease Registry (ATSDR); U.S. Department of Health and Human Services, Public Health Service; Division of Toxicology: Atlanta, GA, USA, 2007. 
41. Obasi, P.N.; Akudinobi, B.E.B. Geochemical assessment of heavy metal distribution and pollution status in soil/stream sediment in the Ameka mining area of Ebonyi state, Nigeria. Afr. J. Geosci. Res. 2015, 3, 1-7.

42. Lukáč, N.; Massányi, P.; Kročková, J.; Nad', P.; Slamečka, J.; Ondruška, L.; Formicki, G.; Trandžík, J. Relationship between trace element concentrations and spermatozoa quality in rabbit semen. Slovak J. Anim. Sci. 2009, 42, 46-50.

43. Al-Rudainy, L.A. Blood lead level among fuel station workers. Oman. Med. J. 2010, 25, 208-211. [CrossRef]

44. Al-Shamri, A.M.J.; Nama, R.S.; Radhi, A.W.; Odda, F.M. Determination of Lead, Cupper, Iron, and Zinc in Blood of Fuel Station Worker at Al-Najaf City. Iraq. Acad. Scientif. J. 2010, 15, 1-10.

45. Buzcu-Guven, B.; Harriss, R. Extent, impacts and remedies of global gas Flaring and venting. Carbon. Manage. 2012, 3, 95-108. [CrossRef]

46. Akinloye, O.; Arowojolu, A.O.; Shittu, O.B.; Anetor, J.I. Cadmium Toxicity: A possible cause of male infertility in Nigeria. Reprod. Biol. 2006, 6, 17-30. [PubMed]

47. Umeyama, T.; Ishikawa, H.; Takeshima, H.; Yoshi, S.; Koiso, K. A Comparative study of Seminal Trace Elements in Fertile and Infertile men. Fertil. Steril. 1986, 46, 494-499. [CrossRef]

48. Makada, M.T.; Amith, S. Levels Cadmium, Chromium, Nickel, Manganese and Lead in normal and pathological human Seminal Plasma. Urol. J. 2005, 72, 461-464.

49. Corradi, P.F.; Corradi, R.B.; Greene, L.W. Physiology of the Hypothalamic Pituitary Gonadal Axis in the Male. Urol. Clin. 2016, 43, 151-162. [CrossRef] [PubMed]

50. Sur, U.; Erkekoglu, P.; Bulus, A.D.; Andiran, N.; Kocer-Gumusel, B. Oxidative stress markers, trace elements, and endocrine disrupting chemicals in children with Hashimoto's thyroiditis. Toxicol. Mech. Methods 2019, 29, 633-643. [CrossRef] [PubMed]

51. Vander, A.; Sherman, J.; Luciano, D. Human physiology: The Mechanisms of Body Function. Smith. J. Med. N. Am. 1998, 56, 8-11.

52. Telisman, S.; Colak, B.; Pizent, A.; Jurasoviæ, J.; Cvitkoviæ, P. Reproductive toxicity of low-level lead exposure in men. Environ. Res. 2007, 105, 256. [CrossRef] 